\title{
Ñe'eng: A voz sertânica do jaguar
}

\section{Leonardo Vieira de Almeida ${ }^{1}$}

RESUMO: Em "Meu tio o Iauaretê", conto incluído no volume Estas estórias, de Guimarães Rosa, o homem-jaguar se constrói na confluência de inúmeros extratos lingüísticos que buscam, fracassadamente, traçar a essência de uma identidade nacional. A fala-rugido, à medida que proseia com o visitante no espaço sertânico, delineia também sua dissolução. Num lapso autofágico, a fala devora a si própria. No entanto, o juaguanhenhém não traça unicamente o dizivel como um encontro com a noite e a morte, mas anuncia, na "selva" do lógos, a descoberta de uma nomeação infante.

ABSTRACT: In "Meu tio o Iauaretê", a short story enclosed in the book Estas estórias, by Guimarães Rosa, the man-jaguar is built in the confluence of countlesses linguistic extracts that unsuccessfully strive to draft the essence of a national identity. The roar-speech, as it talks to the visitor in the space of the "sertão", also delineates its dissolution. In a self-consuming lapse, the speech devours itself. However, the "juaguanhenhém" language does not uniquely drafts the sayable as a meeting with night and death, but it announces, in the "jungle" of the lógos, the discovery of a infant nomination.

PALAVRAS-CHAVE: Guimarães Rosa, conto, semiótica, identidade nacional

KEYWORDS: Guimarães Rosa, short story, semiotics, national Identity

"Meu tio o Iauaretê", conto de João Guimarães Rosa, ocupa na literatura contemporânea um lugar privilegiado, que se destaca pela tentativa de encontrar uma resposta para a seguinte questão: como dar um passo além, tendo em vista o problema da linguagem, matériaprima dos grandes prosadores do século XX? Quando, por exemplo, a experiência de um James Joyce ou um Carlo Emilio Gadda opera no empenho de reconstruir a própria história da língua - no caso, respectivamente, o inglês e o italiano, por meio de um cruzamento de

\footnotetext{
${ }^{1}$ Doutorando em Estudos de Literatura Brasileira na Pontifícia Universidade Católica do Rio de Janeiro (PUC-Rio), Pesquisa: Nas trilhas de Rosa: a problematização do espaço sertão na literatura brasileira.

E-mail: leonardo33vieira@yahoo.com.br
} 
distintos idiomas, dialetos, arcaísmos, distorções semânticas, estruturas oriundas da matemática, da física, do cinema, da engenharia e da música, entre outros —, que desafio estético poderia estabelecer um diálogo que viesse perturbar o instrumento lingüístico em um contexto periférico? Joyce e Gadda, artistas particularmente urbanos, não descuraram de uma profunda reflexão sobre o caráter atópico do progresso e da História nas grandes cidades. Contra uma espécie de No Waste Land propagada pelo capitalismo e seu discurso político se delineia uma cartografia que anuncia as ruínas da própria civilização, as quais só podem ser resgatadas pela reinvenção lingüística. Dublin e Roma são os mapas desta estratégia estética.

Se os escritores europeus vão buscar nas raízes mais atávicas das línguas o insumo para os seus procedimentos de vanguarda - em Finnegans Wake (1939), as reverberações celtas; em Quer pasticciaccio brutto de via Merulana (1957), a tradução gaddiana do estilo macarrônico do burlesco Teófilo Folengo, autor de Baldus (1517) -, Guimarães Rosa estabelece com o tupi, nossa "língua-mater", uma relação inesperada no quadro da literatura brasileira. De fato, a lição romântica marca como traço mais distinto de seu projeto de afirmação do índio, o símbolo nacional, uma irredutível europeização que sustenta o caráter díspare de sua "fala", haja vista o tom erudito que atravessa os diálogos dos autóctones de José de Alencar. Será preciso a Antropofagia de Oswald de Andrade, assentada numa cultura do canibalismo, mas de forma ainda ecolálica, para reivindicar um mais acentuado esforço de assimilação do Outro europeu sem que haja uma assimetria entre o colonizador e o colonizado. No entanto, somente Mário de Andrade, em Macunaíma (1928), vem dar um salto decisivo no que diz respeito a uma representação do índio já não mais como herói nacional, mas como aquele "sem nenhum caráter", emblema oculto e alienado de uma tradição extinta. No entanto, cabe a João Guimarães Rosa, em "Meu tio o Iauaretê", no dizer arguto de Ettore Finazzi-Agró, promover uma "queda sem salvação" da realidade indígena "dentro da 
Voz", em que "as línguas se misturam num todo inextricável, numa wilderness indevassável”.2

No entanto, se para dar corpo a essa Voz Rosa trabalha no interior do tupi, é importante assinalar que esta palavra não só está associada a uma etnia, mas significa: tu (som) e py (pé), assento (apy, apyka). Ou seja, Tupy pode ser traduzido por "som-de-pé", o ser humano. De acordo com Kaka Werá Jacupé, representante da família Guarani dos Werá, o tupi representa uma "tonalidade da Grande Música Divina colocada em pé, encarnada, dentro de um assento chamado corpo-carne, para entoar a criação no mundo terreno, para ser na Terra o que sua essência sagrada é no céu (...)”. ${ }^{3}$ Em tupi, ainda segundo Werá Jecupé, se diz “ñe’eng” para designar a fala humana, mas, também, dependendo do momento, essa noção se aprofunda: “'ñe'eng' ganha o sentido de 'porção divina da alma', 'palavra-alma' $(\ldots) .4$

Nesse caso, a partir de ne'eng, transposto para "Nhem?", Guimarães Rosa prolifera esta partícula indagativa em inúmeras outras construções, como "Nhenhém”? ("Falarfalar?”), "nheengava” (do verbo "nheengar”), “jaguariara” (caçador de jaguar), "jaguanhém” e "juaguanhenhém" (falar como juaguar), "juaguarainhém" e "juaguaranhinhenhém" (falar como filhote de jaguar), "Nhenhenhém..." ("Falarfalarfalar..."). J Já no segundo parágrafo da narrativa, o "ñe'eng"

\footnotetext{
2 Finazzi-Agró se serve do conceito de wilderness - região inculta, mas também deserto, ermo, "sertão" - para estabelecer um estudo comparado entre o conto de Rosa e a novela de Joseph Conrad, The heart of darkness. Se podemos observar tanto no autor mineiro quanto no escritor anglo-polonês uma atitude moderna no que diz respeito ao espaço nacional, desestabilizando suas fronteiras, devemos estar atentos para determinada diferença. Enquanto Conrad nos apresenta o mundo selvagem de Kurtz pelo ponto de vista de um civilizado, no caso o narrador Marlow, Guimarães Rosa penetra o próprio "coração das trevas", permitindo ao leitor ter acesso direto à voz do homem-fera, do índio-branco. Cf. Ettore Finazzi-Agró, Him - it - this voice (entre pátria e mátria), in Um lugar do tamanho do mundo: tempos e espaços em João Guimarães Rosa, p. 129-144.

${ }^{3}$ Cf. Kaka Werá Jecupé, Tupã Tenondé: A criação do Universo, da Terra e do Homem segundo a tradição oral Guarani, p. 79.

4 Idem, ibidem, p. 55.

5 Para a tradução dos termos tupis nos servimos do Dicionário tupi-português, com esboço de gramática tupi antigo, de Luis Caldas Tibiriçá, e de O léxico de Guimarães Rosa, de Nilce Sant'Anna Martins.
} 
funciona como expletivo, primeiro índice de uma cadeia estocástica que se desenvolve ao longo de todo o conto:

Hã-hã. Isto não é casa... É. Havéra. Acho. Sou fazendeiro não, sou morador... Eh, também sou morador não. Eu - tôda a parte. Tou aqui, quando eu quero eu mudo. É. Aqui eu durmo. Hum. Nhem? Mecê é que tá falando. Nhor não... Cê vai indo ou vem vindo?"6 (grifo nosso)

O texto se desenvolve neste diálogo implícito entre um onceiro, mestiço de branco com índia, e um visitante perdido no meio dos Gerais. Além da reverberação da partícula "nhem" no decurso da narrativa, pode-se observar o uso de várias palavras provenientes do tupi, de interjeições, de elipses, e, também, de construções ambíguas, como, por exemplo, quando o onceiro diz que é morador e não é. Acentuando ainda mais o paradoxo, a personagem chega a afirmar: "Eu - tôda a parte”. A esse respeito, torna-se importante atentar para o seguinte ponto: em Grande Sertão: Veredas, publicado alguns anos antes de "Meu tio o Iauaretê", ${ }^{7}$ Riobaldo, de maneira próxima, conta ao senhor (também implícito no diálogo), em visita à sua fazenda, que "O sertão está em toda a parte”. ${ }^{8}$ Assim, é possivel aproximar o sertão como espaço que elide fronteiras, podendo ser a um só tempo "a fora” e "a dentro" - com a Voz do onceiro do conto rosiano. Ou, ainda, o discurso do homem-jaguar se estrutura por meio de uma fala sertânica, a qual se espacializa na "selva" dos nomes, procurando atrair cada vez mais o visitante para o eixo sempre deslocável de sua voragem.

Desse modo, à medida que a personagem implícita no texto vai se acomodando na habitação do onceiro, este conta, sem parar de beber cachaça, como se tornou caçador de onças a mando de Nhô Nhuão Guede. No entanto, esta tarefa executada por dinheiro logo se mostra tormentosa, pois a personagem, que antes pretendia "desonçar êste

\footnotetext{
6 Cf. João Guimarães Rosa, “Meu tio o Iauaretê”, in: Estas estórias, p. 126.

7 O conto em questão, segundo nota do próprio autor, fora escrito em 1955, ou seja, um ano antes da publicação de Grande Sertão: Veredas. Em março de 1961, ele é publicado na revista Senhor, número 25. Posteriormente, faria parte do livro póstumo Estas estórias (1969).

8 Cf. João Guimarães Rosa, Grande Sertão: Veredas, p. 9.
} 
mundo", logo passa a dizer que não pode mais assassinar seus parentes. Começa a alertar o visitante, que possui um cavalo manco, sobre o perigo que cerca o animal, já que há diversas onças que agem na boca da noite. Entrevendo o adversário pelo lume de uma fogueira, o antigo caçador tenta incutir-lhe o medo, mesmo afirmando ser ele um "querembáua", homem bonito e corajoso.

Seguindo essa linha, se apontamos o fato de que a partícula final da palavra tupy, -py, corresponde a pé, assento (apy, apyka), cremos ser importante salientar que a figuração do jaguar, segundo a gênese tupi-guarani, está ligada ao mito de aparecimento de Ñamandu, deus gerador das coisas. Segundo Pierre Clastres, em seus comentários sobre os textos recolhidos por León Cadogan em meio aos guaranis do Paraguai, o termo apyka, um pequeno banco de madeira, geralmente zoomorfo, estaria ligado ao jaguar. Por sinal, os guaranis não dizem "uma criança nasce”, mas "alguém se provê de um assento". Segundo Clastres, o apyka pode ser entendido como o banco o qual "nomeia de forma metonímica a parte do corpo que nele toma lugar: o que a obstetrícia chama, com efeito, de assento". 9

Desse modo, se Guimarães Rosa, como já assinalamos, aglutina as partículas jaguar (yawar) e nhém (ñéeng), de modo a traduzir uma "onciferação" da linguagem, observamos que em ambos os casos os termos da palavra-valise dizem respeito a um ato criador ligado ao som: "ñe'eng", a "palavra-alma"; "yawar", a figura interditada do assento originário, que encarna uma tonalidade da Música Divina colocada em pé. ${ }^{10}$

\footnotetext{
9 O referido comentário diz respeito ao canto "Aparecimento de Ñamandu: os divinos", que faz parte do livro Ayvu Rapyta (1959), de León Candogan, em seu trabalho de compilação dos textos míticos dos mbya-guarani. Cf. Pierre Clastres, A fala sagrada: mitos e cantos sagrados dos índios Guarani, p. 23.

10 Com respeito à representação do jaguar na cultura do continente americano, é fundamental destacar o ensaio de Walnice Nogueira Galvão, "O impossível retorno". Neste texto, a autora aponta a "dimensão mais que brasileira", também americana, mas, sobretudo, latino-americana, do conto de Rosa. Assim, o culto do chamado "jaguar solar" encontra-se, por exemplo, na tradição dos Olmeca da Fase La Venta, no México. Já na épica náhuatl, Quetzalcóatl derrota o Sol Tezcatlipoca que, ao cair do céu, transforma-se em um tigre que a tudo devora, sendo que o mundo fica em trevas. $\mathrm{Na}$ época da conquista espanhola, em Tenochtitlan-Tlateloco, a casta guerreira
} 
Nesse sentido, esta voz, híbrida de nhehengatu e jaguar, se espelha na figuração do onceiro, o qual, à medida que continua relatando suas histórias ao visitante, revela sua familiaridade com as onças, até o instante em que, afinal, afirma ser uma onça: "Eu sou onça... Eu-onça!" 11 Logo a seguir, depois de falar sobre um caçador de onças, Nhuão Inácio, conta ao visitante que o jaguaretê é seu tio.

Assim, um ponto o qual precisa ser destacado é o fato de que o sobrinho do Iauaretê, caçador de diversos jaguares (cangussú, jaguarapinima, pixuna, suçuarana) não deixa de confessar seu parentesco com os mesmos.

Sob esse aspecto, se salientamos a importância do caráter sonoro contido nas partículas que compõem o falar-onça, o "jaguanhém”, não é irrelevante comentarmos o ponto de vista de Ana Luiza Martins Costa em seu ensaio "O mundo escutado", com respeito à outra personagem de Guimarães Rosa que também se expressa por meio de uma voz sertânica, ou seja, aquela concebida na arte de decifrar os sons. Tratase do Chefe Ezequiel, da novela Buriti, cujo exercício de decifração, segundo a autora, remete ao saber dos caçadores. No entanto, se estes reconhecem a voz de cada bicho percebido em fina escuta por dever de ofício, sendo que seu dom possui limites claros e definidos, a tarefa nominadora de Zequiel não tem fronteiras, porque: "Ele vive num mundo que perdeu as paredes. Seu inferno é a ausência de silêncio do mundo. Sua loucura, o excesso de linguagem, a nomeação transbordante e infinda (...)”.12

Em "Meu tio o Iauaretê" assistimos também à história de um "caçador de vozes" que, na sua fala ininterrupta ao visitante, apresenta uma linguagem saturada por índices iconográficos e fonológicos, penetrando os "selvagens rumores" e autênticas "inscrições visuais" na floresta das línguas. Dessa maneira, por meio de uma construção sonoplástico-musical, Guimarães Rosa compõe uma espécie de “canto

12 Cf. Ana Luiza Martins Costa, O mundo escutado, in Revista Scripta, p. 7. 
transbordante", operação tradutória que procura captar a wilderness do homem-onça. Para obter este efeito, além do jogo com as onomatopéias, interjeições e neologismos, na maior parte das vezes construídos por meio de deformações do tupi, há que se ter em vista a ocorrência de diversos metaplasmos, tais como: “aspra” (síncope); "preguntar" (metátese); “estralar” (epêntese); “curuz” (anaptixe ou suarabácti); destemece (prótese); "manheceu” (aférese). ${ }^{13}$

Além desses metaplasmos, o autor mineiro estabelece, mediante determinados procedimentos, uma escrita críptica, a qual se aproxima do ideograma, como, por exemplo, na seguinte passagem: "Faz mal não, rancho não pega fogo, tou olhando, olhôlho"14 (grifo nosso). A aglutinação dos substantivos, com a disposição das vogais orais em "olhôlho", reforça o caráter pictórico, sugerindo o olhar de uma onça inscrito na própria página. Mais adiante, estratégia semelhante é utilizada, dessa vez, com relação ao órgão vocal: “ói: a boca - ói! a bigodeira salta... (grifo nosso) ${ }^{15}$, em que a acentuação e duplicação do “O” procura representar o desenho de uma boca rugindo. Por fim, como mais um índice desta espécie de fala "ideogrâmica"16 - que conjuga som e imagem - podemos destacar o trecho a seguir, no qual o andar da onça, do mesmo modo, se desvela em meio à saturação semiótica do texto, como se por entre a "selva" lingüística acompanhássemos os ecos e rastros das pegadas do Iauaretê, decodificados na composição das

13 Cf. Darcilia Simões e Aira Suzana R. Martins, Fonologia, estilo e expressividade, p. 8-13.

14 Cf. João Guimarães Rosa, Meu tio o Iauaretê, in Estas estórias, p. 128.

15 Idem, ibdem, p. 132.

16 Com relação às características do ideograma chinês, Ernest Fenollosa aponta o fato de que este sinal de notação "fala de imediato com a vividez da pintura e a mobilidade dos sons". Dessa maneira, o ideograma que significa "falar", por exemplo, "é uma boca de onde saem duas palavras e uma chama”. Prossegue o sinólogo norte-americano: "Nesse processo de compor, duas coisas que se somam não produzem uma terceira, mas sugerem uma relação fundamental entre ambas”. Sob esse ponto de vista, podemos reforçar que Rosa, se apropriando de uma escrita fonética, sugere o ideograma por meio da aglutinação de referentes mínimos da língua. $O$ aspecto “terceiro" que se apreende de tal dispositivo não remete a uma síntese, mas a uma ação instantânea, um momento das coisas tende a se representar. Quanto ao problema do ideograma chinês cf. Ernest Fenollosa, Os caracteres da escrita chinesa como instrumento para a poesia, in CAMPOS, Haroldo de (org.), Ideograma: lógica, poesia, linguagem, p. 8-13. 
partículas silábicas "pô”, "pu”: “(...) vai entrando e saindo, maciinho, pôpu, pô-pu, até pertinho da caça que quer pegar" (grifo nosso). ${ }^{17}$

Desenvolvendo sua narrativa por meio desta estrutura ao mesmo tempo musical e plástica, o “onceiro", depois de se revelar um jaguar, vai demonstrando um sentimento de remorso por ter matado seus parentes. É diante da onça Maria-Maria que ele, por fim, cessa sua carreira de caçador a mando de Nhuão Guede. O sobrinho do Iauaretê, seduzido pela beleza da fera, passa a descrevê-la para o visitante. No corpo de Maria-Maria podemos perceber que convivem tanto o mundo animal, o humano e o vegetal, conjugados na sonoridade das aliterações, na duplicação dos vocábulos, nas rimas internas:

Ã-hã. Maria-Maria é bonita, mecê devia de ver! Bonita mais do que alguma mulher. Ela cheira à flor de pau-d'alho na chuva. Ela não é grande demais não. É cangussú, cabeçudinha, afora as pintas ela é amarela, clara, clara. Tempo da sêca, elas inda tão mais claras. Pele que brilha, macia, macia. Pintas, que nenhuma não é preta, não: vermelho escuronas, assim ruivo roxeado. 18

Nesse sentido, a "música" da selva roseana comporta um organismo heteróclito, em que a multiplicidade de planos desempenha uma metamorfose em contínuo movimento. A esse respeito, vale lembrarmos que para Gilles Deleuze e Félix Guattari o corpo musical é percorrido por outros corpos, sejam eles devires-mulher, devirescriança, devires-animal, que tendem a um devir molecular ${ }^{19}$ ou espécie de marulho cósmico, de forma que o inaudivel se faça ouvir, o imperceptível se torne matéria do texto: "não mais o pássaro cantor,

17 Cf. João Guimarães Rosa, Meu tio o Iauaretê, in Estas estórias, p. 133.

18 Cf. João Guimarães Rosa, Meu tio o Iauaretê, in Estas estórias, p. 133.

19 Segundo Deleuze e Guattari, o aspecto "molecular" diz respeito a partículas em movimento, que não possuem formas estáveis. Já o aspecto "molar" se encontra ligado a formas desenvolvidas. Tendo em vista a questão da música, o "molar" corresponde a um plano transcendente de organização, que teria dominado toda a música clássica ocidental. Já o "molecular" estaria ligado a certos músicos modernos, preocupados com um plano sonoro imanente, uma música flutuante, a qual pode ser observada na experiência de John Cage e Stockhausen. Cf. Gilles Deleuze e Félix Guattari, Devirintenso, devir-animal, devir-imperceptível..., in Mil platôs: capitalismo e esquizofrenia, vol. 4 , p. 56. 
mas a molécula sonora". ${ }^{20}$ Por sinal, para os pensadores franceses, os devires, além destas características musicais, também podem ser vistos, na contracorrente da instituição social (totêmica ${ }^{21}$ ou de estrutura), como "fragmentos de contos", que agem em lugares subterrâneos, sendo expressos pela arte dos feiticeiros. Ou seja, "o escritor é um feiticeiro" e "escrever é um devir". Aliás, segundo o Chilam Balam, obra mestra da cultura maia redigida por frades após a conquista espanhola, Balam, um nome de família, significa, no plano figurado, jaguar (onça) ou feiticeiro (bruxo), ${ }^{22}$ o que corrobora o aspecto deste animal sagrado como um criador de mundos, agente da metamorfose.

Tal encenação protéica, realizada no corpo da música, se constitui como uma operação artística realizada, por exemplo, no romance $A$ morte de Virgílio (1958), de Hermann Broch. Particularmente no último capítulo, "Éter - O retorno", o escritor austríaco compõe uma arquitetura sinfônica que procura refletir a desagregação do poeta latino quando de seu transporte final das praias de Bríndisi. Passando pela animalidade primitiva, a espessura vegetal, o limo, até fundir-se ao nada e, num movimento circular, tornar-se novamente o todo, Virgílio ensaia o grande concerto da unidade. Para Maurice Blanchot, em O livro por vir, o romance de Broch seria um "canto fúnebre, Réquiem à maneira de Fauré”. ${ }^{23}$ Esta obra, na qual se realizam as núpcias da morte e da música se abrindo para o éter, poderia ser considerada, no dizer do teórico francês, como o reflexo invertido da literatura de James Joyce, na qual não há unidade, a não ser o grande concerto verbal, o riverrun, que tudo arrasta para um fim e novo começo. Em Broch, há sempre passagem, seja do sentimento ao pensamento, "da experiência bruta a uma experiência mais vasta, recuperada pela reflexão". ${ }^{24} \mathrm{O}$

\footnotetext{
20 Idem, ibdem, p. 32.

21 No que concerne a este ponto, o sacrifício do totem, para Freud, constitui em um gesto que leva do primitivismo à civilização, da natureza à cultura. Já de acordo com Gilles Deleuze e Felix Guatari, o povoamento animal do homem, a proliferação de devires-animais, não se evidencia no totemismo.

22 Cf. Fernando Py, Introdução geral: os livros de Chilam Balam, in: Chilam Balam (o livro sagrado dos maias), p. 12.

23 Cf. Maurice Blanchot, O livro por vir, p. 183.

24 Idem, ibidem, p. 177.
} 
romance do autor austríaco, assentado neste poder reflexivo, por um lado toma partido da clareza e da verdade, e, por outro lado, chama pelo canto, seus acentos líricos e formas musicais. Essa face de Jano, cujos rostos são a reflexão e a música, na opinião de Blanchot "nunca prejudica a compreensão", ${ }^{25}$ aproximando Broch mais de Proust (em seu exercício radical da Recherche) do que de Joyce.

É justamente tomando como espinha dorsal de seu conto esse aspecto musical explorado pelos grandes artistas de vanguarda europeus do século XX, que Guimarães Rosa, em "Meu tio o Iauaretê”, acrescenta-lhe uma nota latino-americana, periférica, por meio de uma imersão nos ritmos da tradição ágrafa, reconcebendo o encontro entre o espaço do canto e o espaço da morte. Nesse sentido, se no romance de Hermann Broch há uma espécie de "equilíbrio" entre os planos do concerto verbal e do enredo das últimas dezoito horas que precedem a morte de Virgílio, enquanto em Joyce a camada preponderante é da corrente musical, principalmente em Finnegans Wake, podemos sustentar o fato de que no conto de Rosa mesclam-se esses diversos limes literários. Há, por sinal, em grande parte da obra do escritor mineiro, um "equilíbrio" entre os torneios semânticos e semióticos, de modo que não se renega a importância da "estória" em detrimento do trabalho de transcriação da linguagem. No caso de "Meu tio o Iauaretê", em meio à "selva" de rugidos e tupinismos, podemos distinguir, mesmo que de maneira entrecortada, a tragédia do "onceiro", no início caçador de onças, e, numa fase posterior, caçador de gente. Quanto à voz "selvática", na qual se expressa a personagem, ela se caracteriza como um processo de zoomorfização em estilhaços que constitui, por exemplo, a chave da técnica de composição de James Joyce em determinada passagem do Finnegans Wake, na qual o escritor irlandês procura reproduzir sons animais em um zôo em Zurichberg, numa noite em formação. ${ }^{26}$ No entanto, se é possivel rastrear no conto rosiano esta

\footnotetext{
25 Idem, ibidem, p. 178.

26 Esta aproximação entre a trama lingüística de "Meu tio o Iauaretê" e o trecho do Finnegans Wake é comentada por Haroldo de Campos no célebre ensaio "A linguagem
} 
preocupação tanto com a forma quanto com a idéia, o que o aproxima da experiência de Broch, podemos dizer que no plano da camada fônica há um liame com Joyce, caracterizado pela escrita telegráfica, cujas pausas por vezes são contrações onomatopéicas como “n’t, n’t”, que sugere o ato de mordiscar do "onceiro", ao contrário das frases do autor austríaco, consideradas por alguns críticos como as maiores da língua alemã. Mas, se levarmos em conta o plano da corrente musical, Guimarães Rosa estaria, mais uma vez, próximo do mestre irlandês, já que em "Meu tio Iauaretê" o canto no coração dos Gerais não acena para a unidade, porém para um lugar "terceiro”, em que a materialidade ou Origem se fraturam irreversivelmente.

No entanto, é justamente em busca desta "Origem" que se move a voz sertânica do Iauaretê, tarefa que tenta recuperar uma determinada sonoridade pura em meio ao estilhaçamento de tonalidades e temas. Atraído pela onça Maria-Maria, na verdade, eco de Mar'Iara Maria, sua mãe índia, o onceiro passa a acreditar que faz parte de uma autêntica estirpe de jaguares, cujo parente último, o tio Jaguaretê, seria a onça verdadeira. Inscrito no nome materno do índio-branco, filho do vaqueiro Chico Pedro, encontra-se Iara, segundo a mitologia dos índios e caboclos difundida após o século XVII, a Mãe D’água, que seduz os homens para a morte. Aliás, numa famosa lenda desses índios e caboclos, a Iara atrai Jaguarari, um moço índio forte como a onça, até afogá-lo nas águas do rio. No caso do onceiro do conto de Rosa, ele parece querer reimergir nas águas primigênias da "Origem”, o tempo perdido da infância em plenitude materna: "Mãe boa, bonita, me dava de-comer muito bom, muito, montão...”. ${ }^{27}$ Por sinal, a água, de acordo com diversas culturas, simboliza tanto a morte quanto a vida, é também luz e palavra. A esse respeito, Gaston Bachelard, em A água e os sonhos, afirma que a água calma, lenta e fluída seria a mestra da linguagem, "que transforma em matéria uniforme os ritmos 
diferentes". ${ }^{28}$ Referindo-se ao poder imagético da água, Bachelard faz menção a Paul Claudel, para quem as águas calmas e lentas simbolizam o desejo de morte: "As águas mansas funcionam como um apelo à morte (...) a morte é uma viagem e a viagem é uma morte. Partir é morrer um pouco”. ${ }^{29}$ Por sua vez, seduzido pelas águas cifradas no nome da onça Maria-Maria, o sobrinho do Jaguaretê, desobedecendo às ordens de seu patrão Nhô Nhuão Guede, de matá-la, logo depois desse gesto tem a vontade de virar onça. Comungando com a noite, a personagem atinge uma experiência-limite, em que o humano potencializa-se no animal e vice-versa, processo que se concebe num espaço contaminado por intenso frio ${ }^{30}$ e solitude:

De noite eu fiquei mexendo, sei nada não, mexendo por mexer, dormir não podia, não; que começa, que não acaba, sabia não, como é que é, não. Fiquei com a vontade... Vontade dôida de virar onça, eu, eu, onça grande. Sair de onça, no escurinho da madrugada... Tava urrando calado dentro de em mim... Eu tava com as unhas... Tinha soroca sem dono, de jaguaretê-pinima que eu matei; saí pra lá. Cheiro dela inda tava forte. Deitei no chão. Eh, frio, frio. Frio vai saindo de todo mato em roda, saindo da parte do rancho... Eu arrupêio. Frio que não tem outro, frio nenhum tanto assim. Gue eu podia tremer, de despedaçar... Aí eu tinha uma câimbra no corpo todo, sacudindo; dei acesso. ${ }^{31}$

Após esse episódio, o índio-branco sente uma força incomum para a caça e, a partir daí, começa a entregar para as onças aqueles a quem odeia: primeiro o preto Bijibo; em seguida, o geralista Riopôro é lançado de um barranco e serve de comida à Porreteira; o fugitivo Guegué

${ }^{28}$ Cf. Gaston Bachelard, A água e os sonhos: ensaio sobre a imaginação da matéria, p. 76.

${ }^{29}$ Cf. Gaston Bachelard, A água e os sonhos: ensaio sobre a imaginação da matéria, p. 77.

30 Quanto à questão do frio que ocupa o espaço onde o sobrinho do Iauaretê se recolhe para sofrer a metamorfose, podemos apontar que fato semelhante ocorre com Riobaldo, quando de sua entrada nas Veredas-Mortas, o ermo maldito no qual se opera o suposto pacto fáustico. Inúmeras vezes o Tatarana se refere ao frio que o cerca, aliás, motivo da cena do encontro de Adrian Leverkühn com o demônio em Palestrina, no romance de Thomas Mann, Doutor Fausto (1947). Nesse sentido, o frio e a solidão enfrentados pela personagem sob o signo da noite e o agenciamento da metamorfose sublinham uma vez mais pontos de contato entre "Meu tio o Iauaretê" e Grande Sertão: Veredas.

${ }^{31}$ Cf. João Guimarães Rosa, Meu tio o Iauaretê, in Estas estórias, p. 149. 
termina devorado pelo Papa-Gente; Antunias, também fugitivo, acaba sob as garras de Maria-Maria. Por fim, acordando um dia na casa do veredeiro Rauremiro, descobre que este, sua mulher, filhas e um menino pequeno estão mortos, banhados em sangue.

Desse modo, inverte-se a ordem do sacrifício, a voz devoradora se nutre não mais de jaguares, mas dos homens. Segundo esse ponto de vista, o canto de morte do Iauaretê procura se voltar contra a tirania exercida por opressores e oprimidos, controlada pela prática de uma violência silenciosa, a qual pode ser subsumida na mira do revólver do visitante, indice de um poder “afirmativo". Mesmo assim, o onceiro confessa ter libertado da morte Maria Quirinéia, mulher do louco Siruvéio, o que aponta ainda uma ligação com os humanos, traço revelador do elo homem-animal, inseparável da personagem. Quanto à esta relação entre a voz e a morte, vale lembrar que, para Giorgio Agamben, a intimidade entre ambas, a qual poderia prescrever um vazio, antes requer ao mesmo tempo o vazio e a potência, enraizados no cerne da linguagem. Tal problema se liga ao fato de que haveria um

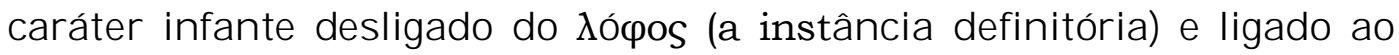
nome (onoma). O pensador italiano salienta que, ao contrário dos animais submetidos à Lei do código genético, a voz do infante, ainda livre de toda prescrição, "não tendo absolutamente nada para dizer ou exprimir, ela seria o único animal de sua espécie que, como Adão, seria capaz de nomear as coisas na sua língua”. ${ }^{32}$ Exige-se, assim, para se atingir a "vocação infantil da linguagem", a morte do que é domesticado na civilização, abrindo a possibilidade do desconhecido.

Revelada a intenção do ex-onceiro, a mira do visitante se apressa em silenciá-lo. Em meio às suas últimas frases, que se pulverizam numa cadeia decrescente de onomatopéias, tupinismos e estilhaços de sentido, surge o nome Macuncôzo. Com relação ao mesmo, Guimarães Rosa, em carta a Haroldo de Campos, revela a nota africana respigada no fim do conto, uma tentativa de identificação? Segundo o autor, com

32 Cf. Giorgio Agamben, Idéia de infância, in Idéia da prosa, p. 92. 
os negros assassinados pelo "índio (onça)", “onça (índio)". ${ }^{33}$ Atitude de remorso ou tentativa de apaziguar seu oponente, mostrando-se ainda humano, tal nota vem se juntar aos outros indices que plurificam o antigo onceiro, impossibilitando o ansiado retorno à Origem, pois ele é ao mesmo tempo onça, índio, branco, negro (?) Diante desta dúvida, o revólver, empunhado por uma "máscara" desconhecida, detém o fluxo de sua violência, num sacrifício da voz da "selva".

Assim, inserindo mais essa semente africana em seu conto, Guimarães Rosa consegue uma contraconquista da mestiçagem, ${ }^{34}$ espécie de "dialética parada"35 íbero-indigenista-americana. Processo que, tendo início no Brasil com Oswald de Andrade no início dos anos 40, quando se refere ao orgulho que nos trouxe a África, alcança o acento trágico fundamental na história de uma voz. Voz a devorar a si própria, numa operação canibalesca em que, na boca estacada na inlatência de Aion, mas redescoberta na promessa das línguas, soa o eco impossível de nossa identidade.

\footnotetext{
33 Cf. Haroldo de Campos, A linguagem do Iauaretê, in: COUTINHO, Eduardo F. (org.), Fortuna crítica de Guimarães Rosa, p. 577-578.

34 A esse respeito, segundo Geraldo Pontes Júnior, uma mestiçagem definitiva da cultura latino-americana ocorreria nas obras de José Lezama Lima e Edouard Glissant, que expressam um devir do Novo Mundo, afastando-se do indigenismo de espírito nacionalista romântico. A antilhanidade de Glissant e o neobarroco de Lezama Lima poderiam ser ilustrados, por exemplo, na arte pictórica e figurativa de Aleijadinho. Cf. Geraldo Ramos Pontes Junior, Crioulidade antilhana, mestiçagem nas Américas e antropofagia brasileira: projetos identitários e (in)correspondências cronológicas, in JOBIM, José Luís e PELOSO, Silvano, Identidade e literatura, p. 134135.

35 O termo "dialética parada", no original alemão "Dialetik im Stillstand", se refere ao conceito de Walter Benjamin no que diz respeito ao encontro entre o Antigo e o Agora. Para o pensador alemão, o presente não é uma luz sobre o passado nem o passado uma luz sobre o presente, mas ocorre um processo distinto, ou seja, uma imagem onde o Antigo encontra o Agora em um raio, de modo a formar uma constelação: "a imagem é a dialética parada (Dialetik im Stillstand). Pois enquanto a relação do presente com o passado é puramente temporal e contínua, a relação do Antigo com o Agora é dialética - não é uma progressão, e sim uma imagem, que salta. Somente as imagens dialéticas são imagens autênticas (isto é, não arcaicas), e o lugar onde são encontradas é a linguagem. Despertar." Cf. Walter Benjamin, Passagens, fragmento N $2 \mathrm{a}, 3$.
} 


\section{Referências Bibliográficas}

AGAMBEN, Giorgio. Idéia da infância. In Ideia da prosa. Trad. João Barrento. Lisboa: Edições Cotovia, 1999.

ANÔNIMO. Chilam Balam (o livro sagrado dos maias). Trad. Fernando Py. Rio de Janeiro: Livraria Editora Cátedra, 1980.

BACHELARD, Gaston. A água e os sonhos: ensaio sobre a imaginação da matéria. Trad. Antonio de Pádua Danesi. São Paulo: Martins Fontes, 1989.

BENJAMIN, Walter. Passagens. Trad. Irene Aron e Cleonice Mourão. Belo Horizonte: Editora UFMG e São Paulo: Imprensa Oficial, 2006.

BLANCHOT, Maurice. A morte de Virgílio: a busca da unidade. In O livro por vir. Trad. Leyla Perrone-Moisés. São Paulo: Martins Fontes, 2005.

BROCH, Hermann. A morte de Virgílio. Trad. Herbert Caro. Rio de Janeiro: Nova Fronteira, 1982.

CAMPOS, Haroldo de. A linguagem do Iauaretê. In COUTINHO, Eduardo F. (org.), Fortuna crítica de Guimarães Rosa. Civilização Brasileira; [Brasília]: INL, 1983.

CLASTRES, Pierre. A fala sagrada: mitos e cantos sagrados dos índios Guarani. Trad. Nícia Adan Bonatti. Campinas: Papirus, 1990.

DELEUZE, Gilles e GUATTARI, Félix. Devir-intenso, devir-animal, devirimperceptível... In Mil platôs: capitalismo e esquizofrenia. Vol. 4. Trad. Suely Rolnik. Rio de Janeiro: Ed. 34, 1997.

FENOLLOSA, Ernest. Os caracteres da escrita chinesa como instrumento para a poesia. In CAMPOS, Haroldo de (org.), Ideograma: lógica, poesia, linguagem. Trad. Heloysa de Lima Dantas. São Paulo: Cultrix, 1986.

FINAZZI-AGRÓ, Ettore. ...Him - it - this voice (entre pátria e mátria). In Um lugar do tamanho do mundo: tempos e espaços da ficção em João Guimarães Rosa. Belo Horizonte: Ed. UFMG, 2001.

FREUD, Sigmund. Totem e tabu. Trad. de Órizon Carneiro Muniz. Rio de Janeiro: Imago Ed., 1999.

GALVÃO, Walnice Nogueira. Indianismo revisitado. In Gatos de outro saco. São Paulo: Brasiliense, 1981.

Paulo: Ática, 1978.

O impossivel retorno. In Mitológica rosiana. São

JECUPÉ, Kaká Werá. Tupã Tenondé: A criação do Universo, da Terra e do Homem segundo a tradição oral Guarani. São Paulo: Peirópolis, 2001.

MARTINS, Nilce Sant'Anna. O léxico de Guimarães Rosa. São Paulo: Editora da Universidade de São Paulo, 2001.

MARTINS COSTA, Ana Luiza. O mundo escutado. In Revista Scripta. Edição especial do III Seminário Internacional Guimarães Rosa (ago. 2004). Belo Horizonte: PUC Minas.

PELBART, Peter Pál. A potência de não: linguagem e política em Agamben. Disponivel

em: http://www.rizoma.net/interna.php?id=326\&secao=artefato. Acesso em: 15 nov. 2007.

PONTES JUNIOR, Geraldo Pontes. Crioulidade antilhana, mestiçagem nas Américas e antropofagia brasileira: projetos identitários e (in)correspondências cronológicas. In JOBIM, José Luís e PELOSO, Silvano (org.), Identidade e literatura. Rio de Janeiro/Roma: de Letras/Sapienza, 2006. 
RIBEIRO, Gonçalves. Histórias e lendas do Brasil. São Paulo: APEL Editora, s. data, 1980.

ROSA, João Guimarães. Grande Sertão: Veredas. 14a. ed. Rio de Janeiro: José Olympio, 1980. Olympio. . Meu tio o Iauaretê. In Estas estórias. Rio de Janeiro: José

SIMÕES, Darcilia e MARTINS, Aira Suzana R. Fonologia, estilo e expressividade. Comunicação apresentada, com o título Fonologia em nova chave, no II Seminário Internacional de Fonologia - PUC/RS, em 15/04/2002.

Disponivel

em: http://www.darcilia.simoes.com/textos/docs/texto09.doc. Acesso em: 9 dez. 2007.

TIBIRIÇÁ, Luis Caldas. Dicionário tupi-português, com esboço de gramática de tupi antigo. Santos: Traço Editora, 1984. 